\title{
COMPARISON OF AGRONOMIC AND QUALITY CHARACTERISTICS OF SOME PEANUT (Arachis hypogaea L.) VARIETIES GROWN AS MAIN AND DOUBLE CROP IN MEDITERRANEAN REGION
}

\author{
Leyla GULLUOGLU ${ }^{1}$, Halil BAKAL ${ }^{1}$, Bihter ONAT $T^{2}$, Cemal KURT ${ }^{1}$, Halis ARIOGLU ${ }^{1 *}$ \\ ${ }^{1}$ Cukurova University, Faculty of Agriculture, Dep. of Field Crop, Adana-Turkey \\ ${ }^{2}$ Cukurova University, Vocational School of Kozan, Adana-Turkey \\ *Corresponding author: halis@cu.edu.tr
}

Received: 14.02 .2017

\begin{abstract}
This study was conducted at the University of Cukurova, Faculty of Agriculture in 2013 and 2014 as a main and double crop growing season. The objective of this study was to compare of agronomic and quality characteristics of some peanut (Arachis hypogaea $\mathbf{L}$.) varieties grown as a main and double crop. The experimental design was a Randomized Complete Block (RCBD) with three replications. The Halisbey, Sultan, Osmaniye-2005, Arioglu-2003, Batem-5025, NC-7, Flower-22, Flower-32, Flower-36, Brantley, Wilson (Virginia market type), Florispan (Spanish market type), Georgia Green (Runner market type) and Spantex (Valencia market type) varieties were used as a plant material in this research. Pod number and pod weight per plant, 100 seed weight, shelling percentage, oil and protein content, pod and kernel yield per hectare values of varieties were compared. The average pod number, pod weight per plant, fancy pod percentage, protein and oil percentage, pod and kernel yield values of peanut varieties were higher in main crop than in double crop, whereas 100 seed weight and shelling percentage were higher in double crop than in main crop growing season. According to a two-year average, the pod yield per hectare of peanut varieties varied between $3366-8796 \mathrm{~kg} \mathrm{ha}^{-1}$ and 3621-7094 $\mathrm{kg} \mathrm{ha}^{-1}$ main and double crop growing season, respectively. The average pod yield of peanut varieties were $6177 \mathrm{~kg} \mathrm{ha}^{-1}$ in main cropped, it was decreased to $5456 \mathrm{~kg} \mathrm{ha}^{-1}$ in double crop growing season. The highest pod yield was obtained from Sultan and Osmaniye-2005 varieties in both growing seasons.
\end{abstract}

Key words: agronomic and quality characteristic, growing season, peanut variety, pod yield

\section{INTRODUCTION}

The world annual unshelled peanut production is around 44 million metric tons in a year and about twothirds of world production is used for oil extraction (Anonymous, 2014a). For this reason, it is an important oil seed crops in the world. Peanut seed contains 44-56\% oil, $22-30 \%$ protein and $9.5-19 \%$ total carbohydrates on dry seed basis and a rich source of minerals and vitamins (Woodroof, 1983; Savage and Keenan, 1994). It uses for human nutrition and animal feeding. Peanut is a legume crop and it fixes about $150 \mathrm{~kg} \mathrm{ha}^{-1}$ nitrogen to soil from the atmosphere by the Rhizobium bacteria living their roots (Arioglu, 2014).

The annual peanut production is around 147.537 tons from the 37.773 ha of production area in Turkey (Anonymous, 2014b). Peanut can be grown at different seasons such as main and double crop for the suitable climate in Mediterranean regions in Turkey. Main and double crop peanut production in the Mediterranean region accounts for $60 \%$ and $40 \%$ of the country's total production, respectively.
Cox (1979), Ketring (1984) and Caliskan et al. (2008) indicated that growth and development of peanut is greatly influenced by environmental factors. The optimum mean air temperature ranges for vegetative growth in peanut is between 25 and $28^{\circ} \mathrm{C}$, which is slightly warmer than the optimum range reported for reproductive growth between 22 and $24{ }^{\circ} \mathrm{C}$. High day temperature above $35^{\circ} \mathrm{C}$ during the reproductive phases reduce dry matter production, proportion of flowers forming pegs, number of pods per plant, individual seed mass, harvest index and pod yield. Crop management practices such as cultivar selection, time of sowing and growing period of varieties may influence the growth, yield and seed quality of peanut. Sowing date is an important production component that can be manipulated to counter the adverse effects of environmental stress.

Prasad et al. (2000) reported that high air temperature had no significant effect on total flower production but significantly reduced the proportion of flowers setting pegs (fruit-set) and hence fruit numbers. In contrast, high soil temperature significantly reduced flower production, the proportion of pegs forming pods and 100-seed weight. 
Canavar and Kaynak (2010) reported that three physiological processes best explain the variation in peanut yields. These are partitioning of assimilate between the reproductive and vegetative structures, the length of the pod filling period and the rate of the pod establishment.

The yield and some agronomic characteristics of peanut are influenced by genotype (growing period) and environmental conditions, particularly temperature during the growing season. Canavar and Kaynak (2008) indicated that planting date had a statistically significant effect on pod yield, days to maturity, number of pods per plant, shelling percentage, pod yield per plant and 100seed weight. The pod yield, shelling percentage, 100-seed weight, the number of pods per plant and pod weight were decreased when the planting delayed to June from May. Laurence (1983) reported that late sowing (May 16) reduced pod yields by $19 \%$ and kernel yields by $18 \%$ compared with early sowing (April 15) and average 100 seed weight was increased by late sowing. Naab et al. (2004) indicated that early planting produced $20 \%$ to $50 \%$ greater pod yields than late planting. Bala et al. (2011) reported that delaying of peanut sowing till mid-July caused a $27.3 \%$ decline in number of pods per plant. When sowing was delayed until end of June or mid-July pod and seed yields declined $44.9 \%$ and $45.2 \%$, respectively relative to sowing in mid-June. Abouziena et al. (2013) found out that delaying planting to mid May decreased the number and weight of pods per plant and seed yield by $20.1 \%, 19.5 \%$ and $18.7 \%$ respectively, compared to early sowing (mid of April). Sarkees (2015) reported that the pod number per plant was decreased from 40.1 to 22.2 pods plant $^{-1}$ and 100 -seed weight increased from 25.8 to $37.4 \mathrm{~g}$ when the planting delayed to June 3 from April 22. Meanwhile he reported that the pod numbers per plant and 100-seed weight of peanut varieties were varied between $29.9-48.0$ pods plant ${ }^{-1}$ and 29.9-35.9 g, respectively.
Isleib et al. (2008) reported that peanut seed composition is influenced by several groups of factors including environmental factors, genetic factors and interaction of these factors. Canvin (1965) showed that the rise of temperature degrees above $20^{\circ} \mathrm{C}$ during seed-filling stage resulted with increase in protein percentage and decrease in oil percentage. Sarkees (2015) reported that protein percentage was decreased from 22.0 to $19.8 \%$, and oil percentage was increased from 39.5 to $44.3 \%$ when the planting delayed to June 3 from April 22. Chowdhury et al. (2015) found out that the oil and protein content of peanut varieties were varied between $49.20-50.76 \%$ and $30.62-38.88 \%$, respectively. Raheja et al. (1987) found out that the oil content of Virginia runner market type peanut varieties was $45.50-52.10 \%$, Virginia bunch types was 47.50-51.90\% and Spanish bunch types was 44.70$54.00 \%$

The agronomic and quality characteristic of peanut varies depending on growing seasons and varieties. The objective of the study was to comparing some agronomic and quality characteristics of peanut varieties grown in Turkey at different growing seasons.

\section{MATERIALS AND METHODS}

\section{Experimental site and materials}

The field trials were conducted during the 2013 and 2014 cropping seasons as a main and double crop at the experimental area of Cukurova University in Adana, Turkey (Southern Turkey, 36 $36^{\circ} 9^{1}$ N, 35 $18^{1}$ E; 23 elevation). The peanut varieties used as a plant material in these researches and their some characteristics are given Table 1.

The soil in the experimental site is classified as clay loam texture. The soil tests in both years indicated a $\mathrm{pH}$ of 7.7 with high concentrations of $\mathrm{K}_{2} \mathrm{O}$ and low concentrations of $\mathrm{P}_{2} \mathrm{O}_{5}$. In addition, the organic matter and nitrogen content of the soil was very low. The lime content was $22.3 \%$ in the upper layers of the soil.

Table 1. Peanut varieties and their some characteristics

\begin{tabular}{lcccl}
\hline Varieties & Market type & Origin & Growing period (days) & Growing type \\
\hline Halisbey & Virginia & Turkey & 150 & Semi-spreading \\
Sultan & Virginia & Turkey & 150 & Semi-spreading \\
Osmaniye-2005 & Virginia & Turkey & 150 & Semi-spreading \\
Arioglu-2005 & Virginia & Turkey & 150 & Semi-spreading \\
Batem-5025 & Virginia & Turkey & 145 & Spreading \\
NC-7 & Virginia & USA & 145 & Spreading \\
Flower-22 & Virginia & Chine & 135 & Semi-spreading \\
Flower-32 & Virginia & Chine & 135 & Semi-spreading \\
Flower-36 & Virginia & Chine & 135 & Semi-spreading \\
Brantley & Virginia & USA & 145 & Spreading \\
Wilson & Virginia & USA & 150 & Spreading \\
Florispan & Spanish & USA & 120 & Erect \\
G. Green & Runner & USA & 130 & Runner \\
Spantex & Valancia & USA & 130 & Erect \\
\hline
\end{tabular}


In Adana, winters are warm and rainy, whereas summers are dry and hot, which is a typical of a Mediterranean climate. The mean monthly air temperature during the research period (April-November) was 17.2 to $28.6^{\circ} \mathrm{C}$ in 2013 , whereas it was in the 14.7 to $29.1^{\circ} \mathrm{C}$ range in 2014. The total rainfall was $89.2 \mathrm{~mm}$ and $172.9 \mathrm{~mm}$ during the growing periods (main and double crop) in 2013 and 2014, respectively. The average relative humidity was ranged from $47.9 \%$ to $72.3 \%$ in 2013 and $62.9 \%$ to $72.6 \%$ in 2014 . The differences between the years and long term for the climatic data were not found very significant (Table 2 ).

Table 2. The climate conditions during the 2013-2014 growing period and long term (LT) average (1950-2015) (Anonymous, 2015)

\begin{tabular}{lccccccccc}
\hline \multirow{2}{*}{ Months } & \multicolumn{3}{c}{ Mean } & temperature $\left({ }^{\mathbf{0}} \mathbf{C}\right)$ & \multicolumn{3}{c}{ Precipitation $(\mathbf{m m})$} & \multicolumn{3}{c}{ Relative humidity $(\%)$} \\
\cline { 2 - 9 } & $\mathbf{2 0 1 3}$ & $\mathbf{2 0 1 4}$ & $\mathbf{L T}$ & $\mathbf{2 0 1 3}$ & $\mathbf{2 0 1 4}$ & $\mathbf{L T}$ & $\mathbf{2 0 1 3}$ & $\mathbf{2 0 1 4}$ & $\mathbf{L T}$ \\
\hline April & 18.1 & 18.3 & 17.5 & 43.2 & 18.6 & 54.7 & 72.0 & 69.2 & 67.3 \\
May & 22.7 & 21.3 & 21.7 & 57.4 & 22.4 & 47.6 & 72.3 & 70.4 & 66.9 \\
June & 25.3 & 24.8 & 25.6 & 0.3 & 1.7 & 19.8 & 65.7 & 70.5 & 68.0 \\
July & 28.2 & 28.2 & 28.1 & 0.0 & 0.3 & 7.0 & 65.2 & 72.6 & 71.6 \\
August & 28.6 & 29.1 & 28.5 & 0.0 & 0.3 & 5.3 & 69.0 & 70.3 & 71.0 \\
September & 25.3 & 25.9 & 25.9 & 15.0 & 80.4 & 17.6 & 63.1 & 64.1 & 65.4 \\
October & 19.5 & 21.0 & 21.3 & 16.5 & 67.8 & 40.6 & 47.9 & 62.9 & 61.6 \\
November & 17.2 & 14.7 & 15.5 & 40.1 & 54.9 & 72.7 & 50.0 & 64.3 & 60.3 \\
\hline
\end{tabular}

\section{The experiment treatments}

The experiments were laid out in a Randomized Complete Block design with three replications in main and double crop separately. Before planting, $250 \mathrm{~kg} \mathrm{ha}^{-1}$ of Di-ammonium phosphate $\left(45 \mathrm{~kg} \mathrm{ha}^{-1} \mathrm{~N}, 115 \mathrm{~kg} \mathrm{ha}^{-1}\right.$ $\mathrm{P}_{2} \mathrm{O}_{5}$ ) was applied in both growing seasons. Mineral fertilizer rates were determined based the nutritional requirements of peanut and soil nutrient availability. Additional nitrogen fertilizer was applied (side-dressing) as a rate of $132 \mathrm{~kg} \mathrm{ha}^{-1}$ in the form of Ammonium nitrate $(33 \% \mathrm{~N})$ before first $(1 / 2$ of $\mathrm{N})$ and second $(1 / 2$ of $\mathrm{N})$ irrigation. The plot size was $14.0 \mathrm{~m}^{2}(2.8 \mathrm{~m} \times 5.0 \mathrm{~m})$ consisting of four rows, five meter long and $70 \mathrm{~cm}$ apart. The seeds were planted by hand as $15 \mathrm{~cm}$ plant spacing. The peanut seeds were treated with fungicide (Thiram) before sowing against to Aspergillus Crown Rot (Aspergillius niger van Tieghem). The planting date was April 10 and the harvesting date was October 5 in main crop growing season and June 15 was planting date and November 10 was harvesting date in double crop growing season in both years. The plants harvested by hand when the $60 \%$ of the pods are matured in both growing seasons. During the growing period, some cultural practices such as weed control, irrigation, pesticide and fungicide were applied at the proper time intervals for each experiment.

\section{Data collection and measurement}

Pod number and pod weight per plant and fancy pod number percentage was collected from 20 plants randomly selected from each plot at the harvesting time. Yield data per plot was measured in a similar way from all remaining plants excluding the very end on each side of the two central rows. 100-seed weight and shelling percentage data were obtained after harvesting (Gulluoglu et al. 2016a). Kernel yield was calculated as the ration of pod yield $x$ shelling percentage (Rasekh et al. 2010). The oil and protein percentage was estimated according to Association of Official Analytical Chemists (AOAC, 2010).

The data were statistically analyzed by JUMP 8.1.0 statistical software with Split Plot Design. Least Significant Differences (LSD) test was used to compare the treatments at probability level of 0.05 .

\section{RESULTS AND DISCUSSION}

According to a two-year average, the data were statistically analyzed using split plot design and obtained values belonging to least significant differences (LSD) for the growing seasons, varieties, and growing season $\mathrm{x}$ variety interaction are presented in Table 3 .

It can be seen in Table 3, the results indicated that the differences between the varieties were statistically significant for all the investigated traits in both growing seasons. The differences between the growing seasons and interaction of growing season $\mathrm{x}$ variety were significant for all traits except shelling percentage. The differences between the growing seasons and interaction of variety $\mathrm{x}$ growing season for the shelling percentage were not significant. 
Table 3. Least significant differences (LSD, 5\%) values belonging to agronomic and yield traits of peanut varieties grown in different seasons (for two years average)

\begin{tabular}{lccccccccc}
\hline Treatments & PD & PW & FP & SW & PC & OC & SP & PY & KY \\
\hline $\begin{array}{l}\text { Variety } \\
\text { (Amain crop) }\end{array}$ & 3.563 & 7.314 & 4.159 & 2.873 & 0.508 & 0.800 & 1.742 & 584.6 & 520.3 \\
$\begin{array}{l}\text { Variety } \\
\text { (Adouble crop) }\end{array}$ & 2.088 & 3.240 & 3.498 & 2.565 & 1.360 & 1.903 & 1.808 & 209.9 & 209.6 \\
Growing season & 0.830 & 1.290 & 1.061 & 0.724 & 0.296 & 0.299 & NS & 124.0 & 79.9 \\
(B) & 3.104 & 4.827 & 3.970 & 2.707 & 1.108 & 1.119 & NS & 464.1 & 298.9 \\
\hline AxB & & & & & & &
\end{tabular}

$\mathrm{PD}=$ Pod number, $\mathrm{PW}=$ Pod weight, $\mathrm{FP}=$ Fancy pod, $\mathrm{SW}=100$ seed weight, $\mathrm{SP}=$ Shelling percentage, $\mathrm{OC}=$ Oil content, $\mathrm{PC}=$ Protein content, $\mathrm{PY}=\mathrm{Pod}$ yield and KY=Kernel yield

\section{Pod number per plant}

The comparison of average pod number per plant of peanut varieties grown in main and double crop growing seasons is shown in Figure 1.

The results for the pod number per plant obtained in this study showed that the differences between the growing season and varieties were statistically significant (Table 3). According to two years average, while the pod number per plant of varieties was 30.96 pods $_{\text {plant }}{ }^{-1}$ in main crop, it was decreased to 28.87 pods plant $^{-1}$ in double crop growing season (Figure 1). Prasad et al. (2000) reported that high air temperature at the reproductive growing period significantly reduced the proportion of flowers setting pegs (fruit-set) and hence fruit numbers. Cox et al. (1979) and Ketring (1984) indicated that high day temperature above $35^{\circ} \mathrm{C}$ during the reproductive phases reduce dry matter production, proportion of flowers forming pegs and number of pods per plant. The air temperature during the flowering and pod formation period was higher in double crop than in main crop (Table 2).

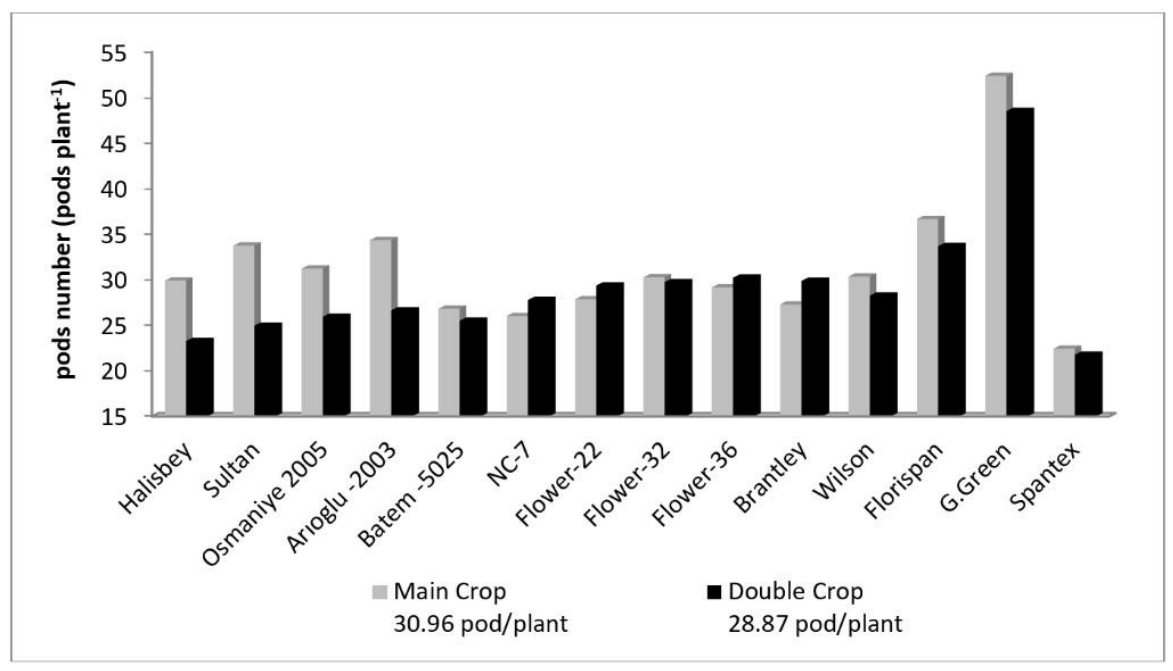

Figure 1. The Comparison of average pod number per plant of peanut varieties grown in main and double crop growing seasons

The pod number per plant of peanut varieties varied between 22.44-52.40 pods plant ${ }^{-1}$ in main crop and 21.78 48.53 pods plant ${ }^{-1}$ in double crop. Among the peanut varieties, the lowest $\left(22.44\right.$ and 21.78 pods plant $^{-1}$ ) pod number plant $^{-1}$ was obtained from Spantex and the highest (52.40 and 48.53 pods plant ${ }^{-1}$ ) from Georgia Green in main and double crop, respectively (Fugure 3). Spantex is a Valancia market type peanut variety and growing as erect whereas Georgia Green is a runner type variety and growing as a runner. Runner type peanut varieties produce more branches and higher pod number than Valancia type varieties. Canavar and Kaynak (2008) indicated that planting date had a statistically significant effect on number of pods per plant and the number of pods per was decreased when the planting delayed to June from
May. Bala et al. (2011) reported that delaying of peanut sowing till mid-July caused a $27.3 \%$ decline in number of pods per plant. Abouziena et al. (2013) found out that delaying planting to mid May decreased the number of pods per plant compared to early sowing (mid of April). Sarkees (2015) reported that the pod number per plant was decreased from 40.1 to 22.2 pods plant $^{-1} \mathrm{~g}$ when the planting delayed to June 3 from April 22.

Between the growing season and variety interaction on pod number per plant was statistically significant (Table 3 ). According to a two-year average the pod number per plant was highest $\left(52.40\right.$ pods plant $\left.^{-1}\right)$ in Georgia Green in main crop and the lowest (21.78 pods plant ${ }^{-1}$ ) was in Spantex in double crop (Figure 1). These results are in agreement with the findings of Caliskan et al. (2008), 
Canavar and Kaynak (2008), Bala et al. (2011), Abouziena et al. (2013) and Sarkees (2015).

\section{Pod weight per plant}

The pod weight plant $^{-1}$ was $11.9 \%$ higher in main cropping $\left(70.80 \mathrm{~g}\right.$ plant $\left.^{-1}\right)$ compared to the double cropping (62.48 $\mathrm{g} \mathrm{plant}^{-1}$ ) growing season (Figure 2). The difference between the growing seasons and peanut varieties for the pod weight per plant were statistically significant (Table 3). The yield and some agronomic characteristics of peanut are influenced by genotype (growing period) and environmental conditions, particularly temperature during the growing season. Canavar and Kaynak (2008) indicated that planting date had a statistically significant effect on pod yield per plant. The pod weight was decreased when the planting delayed to June from May.

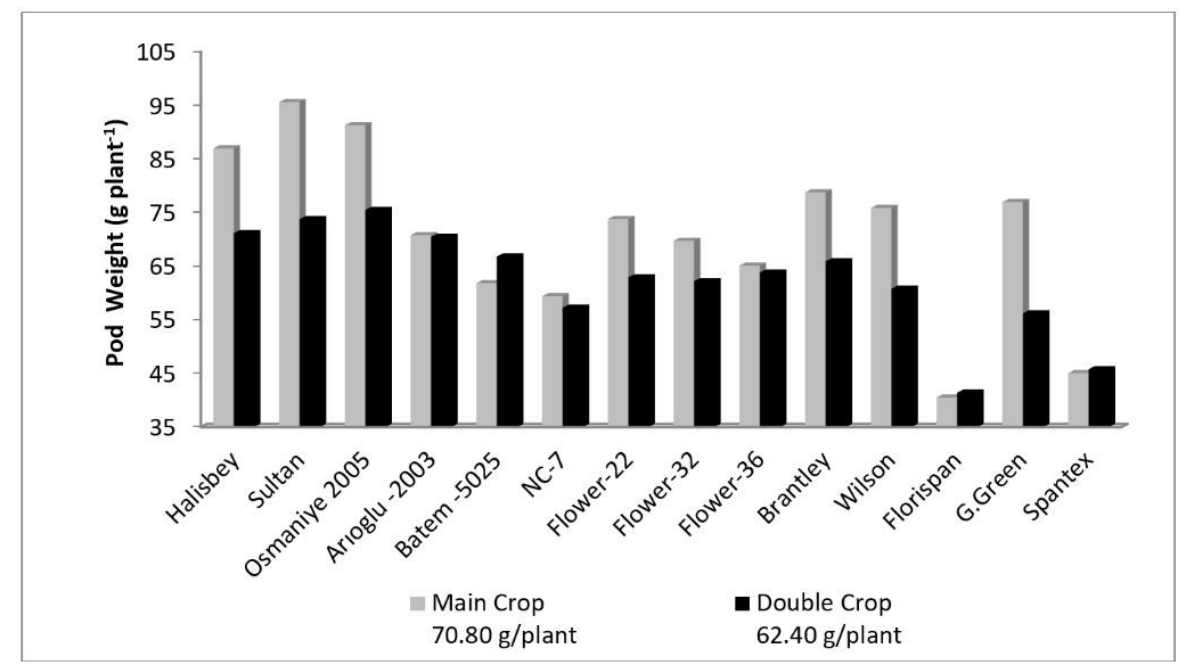

Figure 2. The Comparison of average pod weight per plant of peanut varieties grown in main and double crop growing seasons

As it can be seen Figure 2, the pod weight per plant of peanut varieties were ranged from $40.50 \mathrm{~g}$ to $95.55 \mathrm{~g}$ plant $^{-1}$ in main crop and from $41.40 \mathrm{~g}$ to $75.46 \mathrm{~g} \mathrm{plant}^{-1}$ in double crop. The pod weight per plant of peanut varieties was higher in main crop than in double crop. Canavar and Kaynak (2010) reported that three physiological processes best explain the variation in peanut yields. These are partitioning of assimilate between the reproductive and vegetative structures, the length of the pod filling period and the rate of the pod establishment. The pod filling period was longer and the rate of the pod establishment was higher in main crop than in double crop growing season. The yield and some agronomic characteristics of peanut are influenced by genotype (growing period) and environmental conditions, particularly temperature during the growing season. Canavar and Kaynak (2008) indicated that planting date had a statistically significant effect on pod yield per plant and the pod weight per plant was decreased when the planting delayed to June from May. Abouziena et al. (2013) found out that delaying planting to mid May decreased the weight of pods per plant $19.5 \%$ compared to early sowing (mid of April).

The pod weight was the highest in Sultan (95.55 g plant $\left.^{-1}\right)$ and Osmaniye-2005 (75.46 g plant $\left.^{-1}\right)$ in main and double crop, respectively and the lowest in Florispan
(40.50 and $41.40 \mathrm{~g} \mathrm{plant}^{-1}$ ) in both growing seasons. Virginia market type peanut varieties had larger pods and seeds compared to other market types. Abouziena et al. (2013) found out that delaying planting to mid May decreased the weight of pods per plant $19.5 \%$ compared to early sowing (mid of April). Between the growing season and variety interaction on pod weight per plant was statistically significant (Table 3). According to two years average, the highest pod weight was obtained from Sultan (95.55 $\left.\mathrm{g} \mathrm{plant}^{-1}\right)$ and the lowest from Florispan (40.50 g plant $^{-1}$ ) in main crop growing season (Figure 2). The results are corresponded well with the findings of Canavar and Kaynak (2008) and Abouziena et al. (2013).

\section{Fancy pod percentage}

Fancy pod mean is a high quality pods in peanut production. Fancy pods percentage needs as a high by the peanut producers. In this research, the results indicated that growing season had significant effect on fancy pod percentage. The fancy pod number percentage was $2.25 \%$ higher in main crop than in double crop. The differences between the growing seasons for the fancy pod percentage were significant (Table 3). According to two years average, while the fancy pod percentage was $79.21 \%$ in main crop it was decreased to $76.96 \%$ in double crop growing season (Figure 3). 


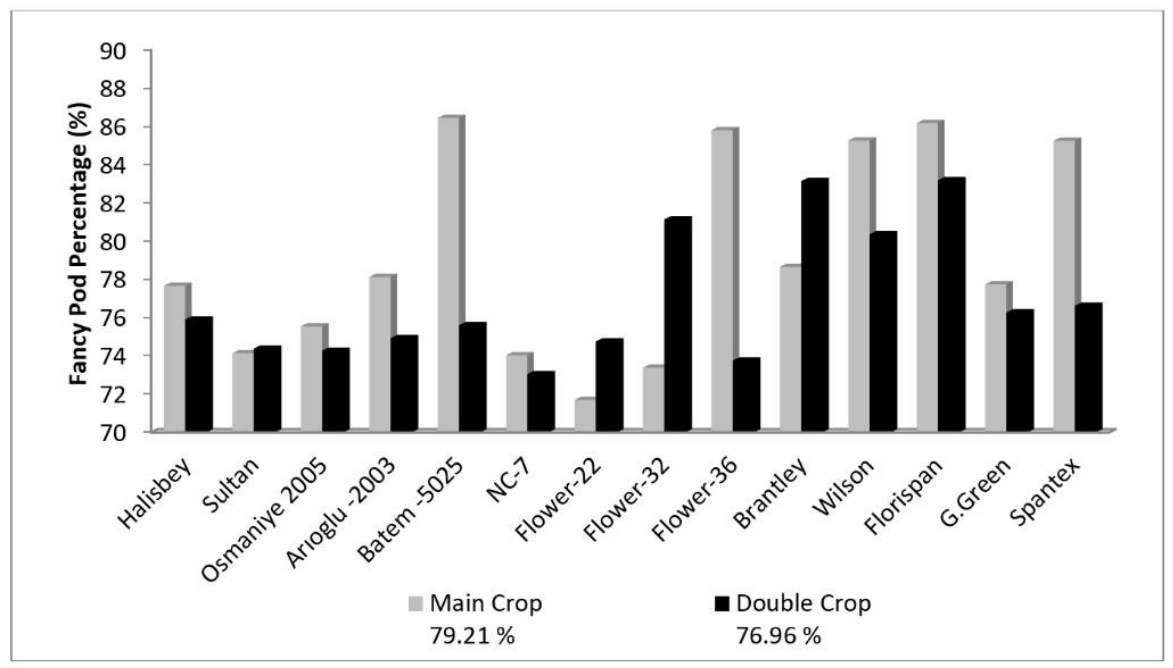

Figure 3. The Comparison of average fancy pod percentage of peanut varieties grown in main and double crop growing seasons

The differences between the varieties for the fancy pod number were statistically significant in both growing season (Table 3). Among the varieties, the lowest and highest fancy pod percentage was obtained from NC-7 $(73.07 \%$ and $73.05 \%)$ and Florispan $(86.48 \%$ and $83.19 \%)$ in main and double crop, respectively (Figure 3). The fancy pod percentage of peanut varieties was higher as compared to the double crop. According to two years average, between the growing season and variety interaction on fancy pod number percentage was statistically significant. The highest fancy pod percentage was obtained from Florispan (86.48\%) and the lowest from Flower-22 (72.70\%) in main crop growing season. The result is supported by the findings of Kvien and Bergmark (1987).

\section{Seed weight}

The effect of growing season on the 100-seed weight was found significant (Table 3). The average hundred seed weight of peanut varieties was $114.08 \mathrm{~g}$ in main crop and was $115.20 \mathrm{~g}$ in double crop growing season (Figure 4).

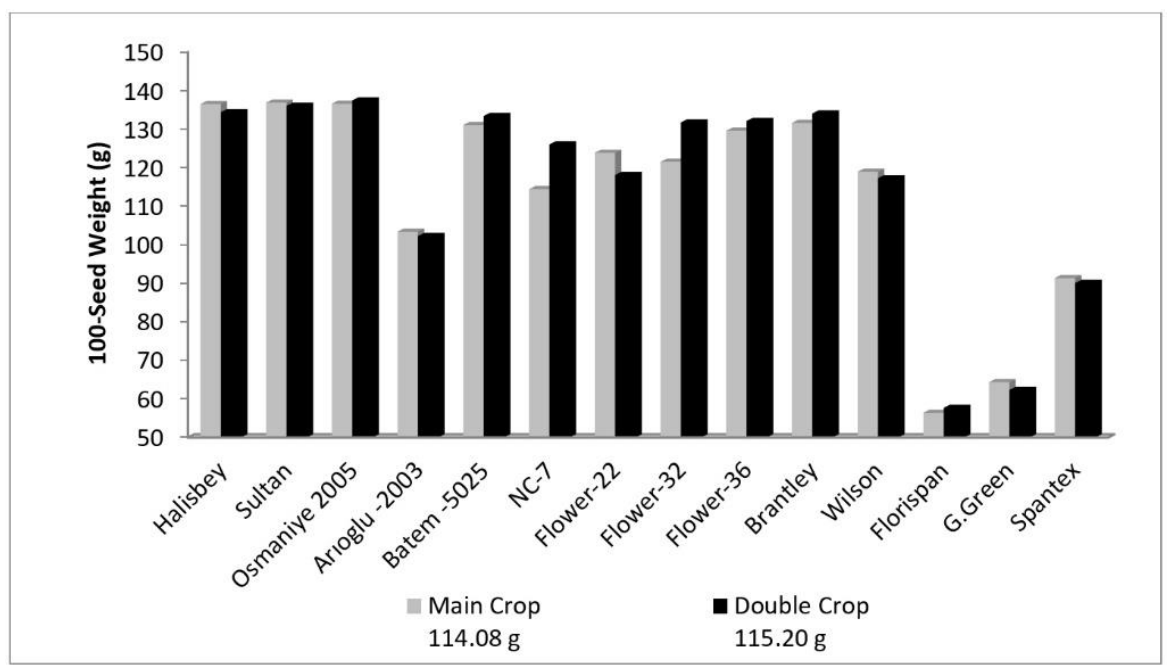

Figure 4. The Comparison of average 100-seed weight of peanut varieties grown in main and double crop growing seasons

The 100-seed weight was found higher in double crop than in main crop. Cox (1979), Ketring (1984) and Caliskan et al. (2008) indicated that the optimum mean air temperature ranges for reproductive growth between 22 and $24^{\circ} \mathrm{C}$. High day temperature above $35^{\circ} \mathrm{C}$ during the reproductive phases reduces dry matter production and individual seed weight. The air temperature was higher in main crop (28.2 and $28.6^{\circ} \mathrm{C}$ in July and August) than in double crop (25.9 and $21.0^{\circ} \mathrm{C}$ in September and October) at the pod filling period (Table 2). For this reason, the 100 -seed weight was higher in double crop growing season.

The 100-seed weight was varied between 56.42-136.85 $\mathrm{g}$ in main crop and between $57.69-137.43 \%$ in double crop growing season (Figure 4). The results indicated that growing seasons had significant effect on 100-seed weight. Main and double crop growing season compared for the 100-seed weight of peanut varieties, some varieties 
such as Sultan, Halisbey, Arioglu-2005, Flower-22, Wilson, G.Green and Spantex have higher 100-seed weight in main crop than in double crop. The other varieties such as Osmaniye-2005, Batem-5025, NC-7, Flower-32, Flower-36, Brantley and Florispan were higher in double crop than in main crop growing season (Figure 4). Growing season $x$ variety interaction on 100-seed weight of peanut was statistically significant. The highest 100-seed weight was obtained from Sultan (136.85 g) in main crop and Osmaniye-2005 (137.43 g) in double crop, and the lowest from Florispan $(56.42 \mathrm{~g}$ and $57.69 \mathrm{~g})$ in both growing season (Figure 4). The yield and some agronomic characteristics of peanut varieties are influenced by genotype (growing period) and environmental conditions, particularly temperature during the growing season. Canavar and Kaynak (2008) indicated that planting date had a statistically significant effect on 100 -seed weight and the 100-seed weight was decreased when the planting delayed to June from May. Laurence (1983) reported that the average 100-seed weight was increased by late sowing. Sarkees (2015) reported that the 100-seed weight was increased from 25.8 to $37.4 \mathrm{~g}$ when the planting delayed to June 3 from April 22. These results are in agreement with the findings of Laurence (1983), Prasad et al. (2000) and Sarkees (2015) and disagreement with the findings of Canavar and Kaynak (2008).

\section{Protein percentage}

It can be seen in Table 3, the differences between the growing seasons and varieties for the protein percentage were statistically significant. The protein percentage was higher in main crop $(27.16 \%)$ than in double crop $(24.09 \%)$ (Figure 5). Isleib et al. (2008) reported that peanut seed composition is influenced by several groups of factors including environmental factors, genetic factors and interaction of these factors. Canvin (1965) showed that the rise of temperature degrees above $20^{\circ} \mathrm{C}$ during seed-filling stage resulted with increase in protein percentage. Sarkees (2015) reported that protein percentage was decreased from 22.0 to $19.8 \%$, when the planting delayed to June 3 from April 22.

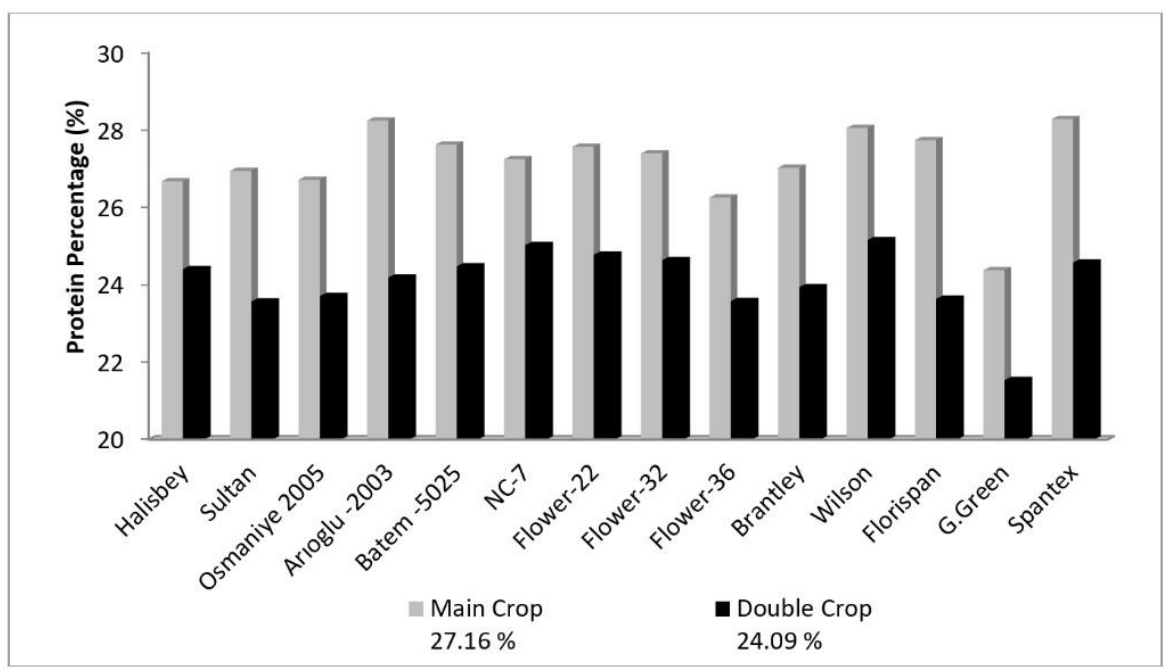

Figure 5. The Comparison of average protein percentage of peanut varieties grown in main and double crop growing seasons

Among the peanut varieties, the lowest and the highest protein percentage was $24.38 \%$ (G.Green) and $28.29 \%$ (Spantex) in main crop and $21.54 \%$ (G.Green) and $25.16 \%$ (Wilson) in double crop, respectively (Figure 5). The result indicated that the peanut varieties had significantly higher protein percentage in main crop than in double crop. Chowdhury et al. (2015) indicated that protein is the major nutrient components of different varieties of peanut. Protein content genetically controlled. Growing season $\mathrm{x}$ variety interaction on protein percentage of peanut was statistically significant (Table $3)$. The highest protein content was obtained from Spantex $(28.29 \%)$ in main crop and the lowest from G.Green $(21.54 \%)$ in double crop growing season (Figure 5).
Similar findings have been reported on peanut by Caliskan et al. (2008) and Sarkees (2015).

\section{Oil percentage}

There were significant differences between growing seasons and peanut varieties for the oil content (Table 3). The oil percentage was higher in main crop (48.92\%) than in double crop (46.56\%) (Figure 6). Isleib et al. (2008) reported that peanut seed composition is influenced by several groups of factors including environmental factors, genetic factors and interaction of these factors. Knauft et al. (1986), Abouziena et al. (2013) and Gulluoglu et al. (2016b) indicated that early sowing significant produced more oil yield than the later sowing. 


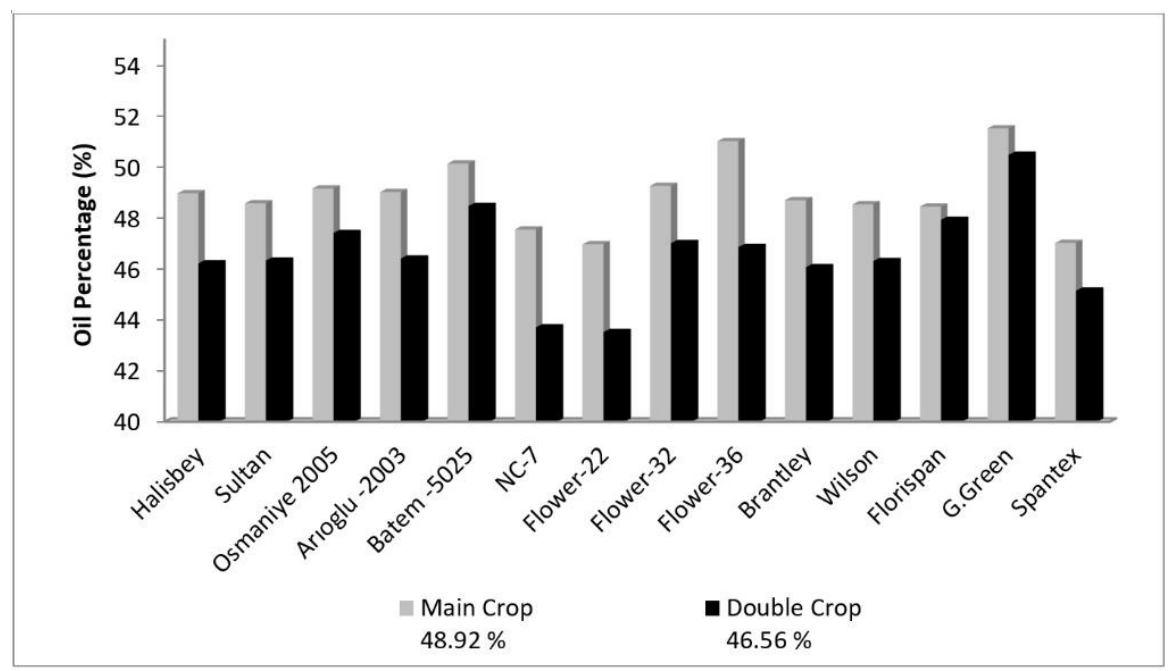

Figure 6. The Comparison of average oil percentage of peanut varieties grown in main and double crop growing seasons

The oil percentage of peanut varieties varied between $46.97-51.52 \%$ in main crop and $43.52-50.48 \%$ in double crop growing season. Main crop gave significantly higher oil percentage as compared to the double crop. The highest oil percentage was obtained from G.Green and the lowest from Flower-22 in both growing seasons (Figure 6). Brown et al. (1975) and Holaday and Pearson (1974) reported that genotypic differences for oil content were highly influenced by location, seasons and growing conditions in peanut. Raheja et al. (1987) indicated that oil content of peanut variety is independent on the growth habit of the peanut as no marked differences were observed in the mean oil content among the peanut groups. Genotype x growing seasons interaction effects were highly significant for oil content (Table 3). The highest oil content was obtained from G.Green $(51.52 \%)$ in main crop and the lowest from Flower-22 (43.52\%) in double crop growing season (Figure 6). The results are corresponded well with the findings of Knauft et al. (1986), Abouziena et al. (2013) and Gulluoglu et al. (2016b).

\section{Shelling percentage}

The effect of growing season on the shelling percentage was not found statistically significant (Table 3). The average shelling percentage of peanut varieties was $68.82 \%$ in main crop and was $68.97 \%$ in double crop growing season (Figure 7). The shelling percentage was found higher in double crop than in main crop. The differences between the day and night temperature is higher in double crop than in main crop growing season at the pod filling period. The dry matter production was increased in double crop. For this reason, the shelling percentage was higher in double crop growing season. Similar findings have been reported on peanut by Caliskan et al. (2008).

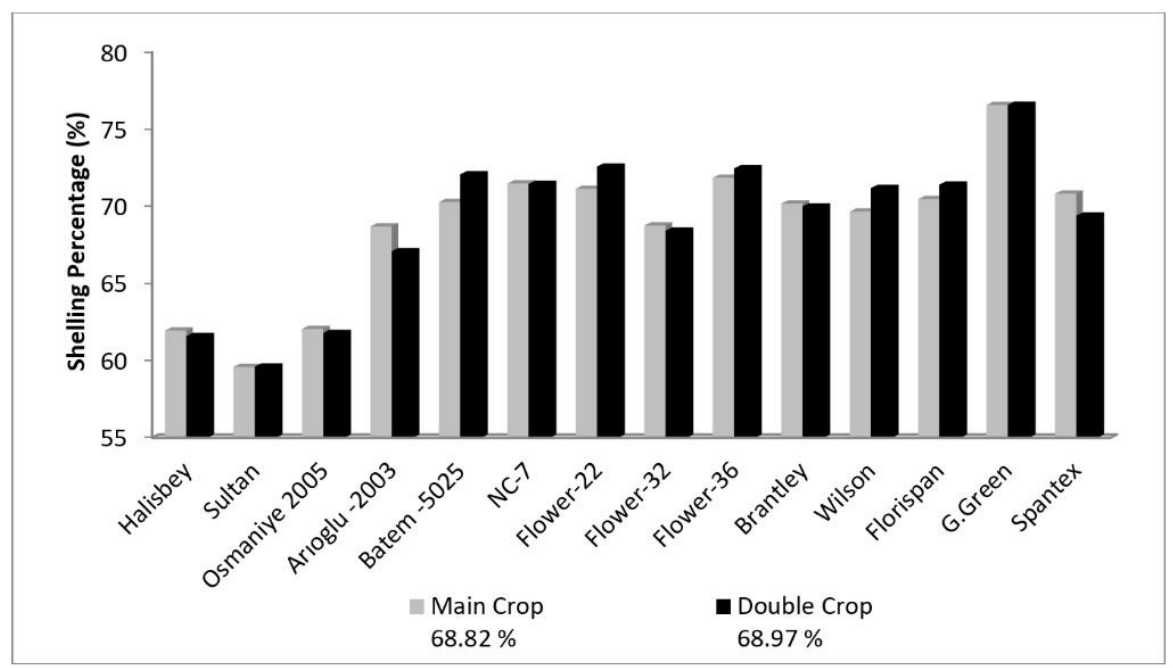

Figure 7. The Comparison of average shelling percentage of peanut varieties grown in main and double crop growing seasons

The shelling percentage of peanut varieties ranged from 59.59 to $76.57 \%$ in main crop and ranged from 59.61 to $76.58 \%$ in double crop growing season (Figure 7). The differences between the peanut varieties for the shelling 
percentage were found statistically significant (Table 3). The highest selling percentage was obtained from G.Green and the lowest from Sultan in both growing seasons. Halisbey, Osmaniye-2005, Arioglu-2003, NC-7, Flower-32, Brantley and Spantex varieties had higher shelling percentage in main crop than in double crop. In contrast, Sultan, Batem-5025, Flower-22, Flower-36, Wilson, Florispan and G.Green varieties had lower shelling percentage in main crop than in double crop. When the peanut varieties compared for the shelling percentage at different growing seasons, the shelling percentage values was lower in main crop than in double crop (Figure 7). Some agronomic characteristics and seed composition of peanut are influenced by several groups of factors including environmental factors, genetic factors and interaction of these factors (Isleib et al., 2008).
Canavar and Kaynak (2008) indicated that planting date had a statistically significant effect on shelling percentage and the shelling percentage was decreased when the planting delayed to June from May. The results indicated that according to two years average, between the growing season and variety interaction on shelling percentage was not statistically significant (Table 3).

\section{Pod yield}

It can be seen in Figure 8, while the average pod yield per hectare was $6177 \mathrm{~kg} \mathrm{ha}^{-1}$ in main crop and it was 5456 $\mathrm{kg} \mathrm{ha}^{-1}$ in double crop growing season. The differences between the growing seasons for the pod yield were significant (Table 3 ). The pod yield values were higher in main crop than in double crop.

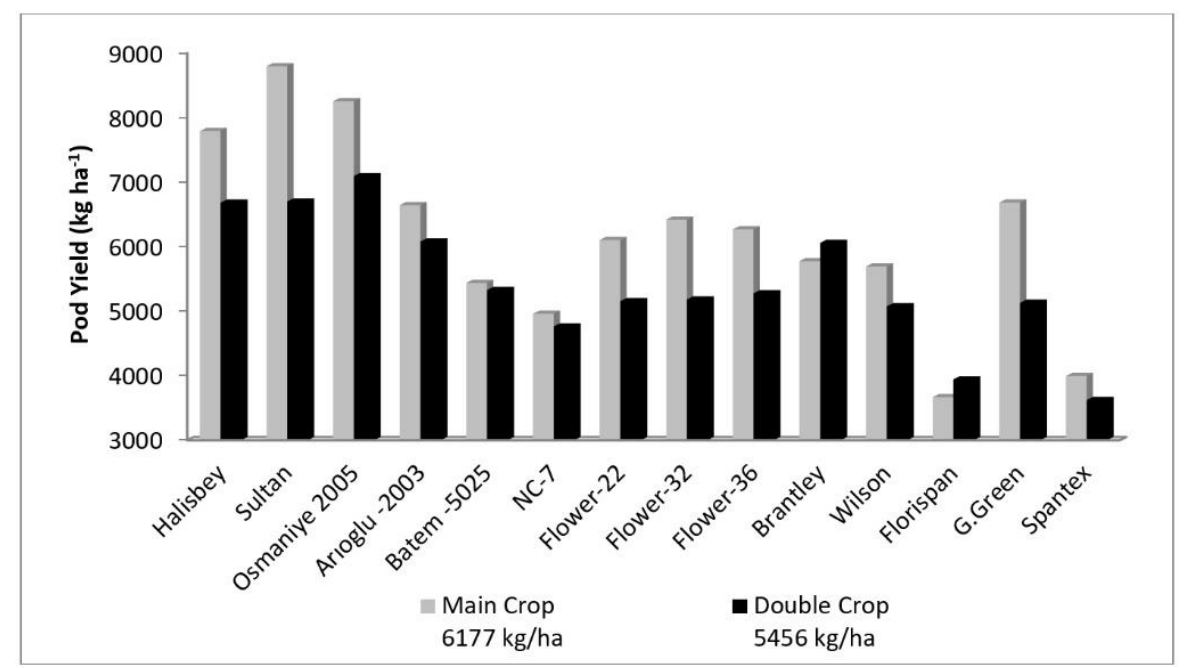

Figure 8. The Comparison of average pod yield of peanut varieties grown in main and double crop growing seasons

Canavar and Kaynak (2010) reported that three physiological processes best explain the variation in peanut yields. These are partitioning of assimilate between the reproductive and vegetative structures, the length of the pod filling period and the rate of the pod establishment. The pod filling period was longer and the rate of the pod establishment was higher in main crop than in double crop growing season. Flowering and pod formation in peanut were higher in long day than short day conditions. The day length was longer in main crop than in double crop in Cukurova region. For these reasons pod number and pod weight per plant was found higher in main crop (Figure 1 and 2). These two characteristics are very important yield component and effects on pod yield per hectare in peanut. As a result, the average pod yield was higher in main crop growing season.

The differences between the peanut varieties for the pod yield per hectare were statistically significant (Table 3 ). The pod yield $\mathrm{ha}^{-1}$ values of peanut varieties varied between 3666-8796 $\mathrm{kg} \mathrm{ha}^{-1}$ in main crop and 3621-7094 $\mathrm{kg} \mathrm{ha}^{-1}$ in double crop growing season. Peanut yield is calculated by multiplying the plant number per unit area $\mathrm{x}$ pod weight per plant. In this research, the pod weight per plant of peanut varieties was higher in main crop than in double crop growing season (Figure 2). When the peanut varieties compared for the pod yield at different growing seasons, the average yield values was $11.7 \%$ higher in main crop than in double crop. The yield differences between the varieties was about $2.0 \%$ in some variety (Batem-5025), it was about $23.8 \%$ in other variety (Sultan). The reason of this difference was the genotypic back ground of peanut varieties and genotype $\mathrm{x}$ environment interaction. The results indicated that according to two years average, between the growing season and variety interaction on pod yield was statistically significant (Table 3). Among the peanut varieties, the highest pod yield was obtained from Sultan $\left(8796 \mathrm{~kg} \mathrm{ha}^{-1}\right)$ and Osmaniye-2005 (7094 $\left.\mathrm{kg} \mathrm{ha}^{-1}\right)$ in main and double crop growing seasons, respectively, and the lowest from Florispan (3666 kg ha-1) in main crop and from Spantex (3621 kg ha-1) in double crop growing season (Figure 8).

Cox (1979), Ketring (1984) and Caliskan et al. (2008) indicated that crop management practices such as cultivar selection, time of sowing and growing period of varieties may influence the growth, yield and seed quality of 
peanut. Sowing date is an important production component that can be manipulated to counter the adverse effects of environmental stress. The yield and some agronomic characteristics of peanut are influenced by genotype (growing period) and environmental conditions, particularly temperature during the growing season. Canavar and Kaynak (2008) indicated that planting date had a statistically significant effect on pod yield per plant and pod yield per hectare. The pod yield, the number of pods per plant and pod weight per plant was decreased when the planting delayed to June from May. Laurence (1983) reported that late sowing (May 16) reduced pod yields by $19 \%$ and kernel yields by $18 \%$ compared with early sowing (April 15). Naab et al. (2004) indicated that early planting produced $20 \%$ to $50 \%$ greater pod yields than late planting. Bala et al. (2011) reported that delaying of peanut sowing till mid-July caused a $27.3 \%$ decline in number of pods per plant. When sowing was delayed until end of June or mid-July pod and seed yields declined $44.9 \%$ and $45.2 \%$, respectively relative to sowing in midJune. Abouziena et al. (2013) found out that delaying planting to mid May decreased the seed yield by $18.7 \%$ compared to early sowing (mid of April). These results are in agreement with the findings of Laurence (1983), Naba et al. (2004), Canavar and Kaynak (2008), Bala et al. (2011), Abouziena et al. (2013) and Sarkees (2015).

\section{Kernel yield}

The average kernel yield of peanut varieties was 4202 $\mathrm{kg} \mathrm{ha}^{-1}$ in main crop and it was $3729 \mathrm{~kg} \mathrm{ha}^{-1}$ in double crop growing season (Figure 9). The differences between the growing seasons for the kernel yield were statistically significant (Table 3). The kernel yield values were higher in main crop than in double crop. Kernel yield was calculated as the ration of pod yield $\left(\mathrm{kg} \mathrm{ha}^{-1}\right) \mathrm{x}$ shelling percentage (\%). The differences between the growing seasons for the shelling percentage were not significant, whereas between the pod yield was significant and the pod yield was higher in main crop than double crop (Table 3). As a result, the average kernel yield was higher in main crop than in double crop growing season. Laurence (1983), Naab et al. (2004), Canavar and Kaynak (2008), Caliskan et al. (2008) and Abouziena et al. (2013) reported that kernel yield values decreased with delaying the sowing date.

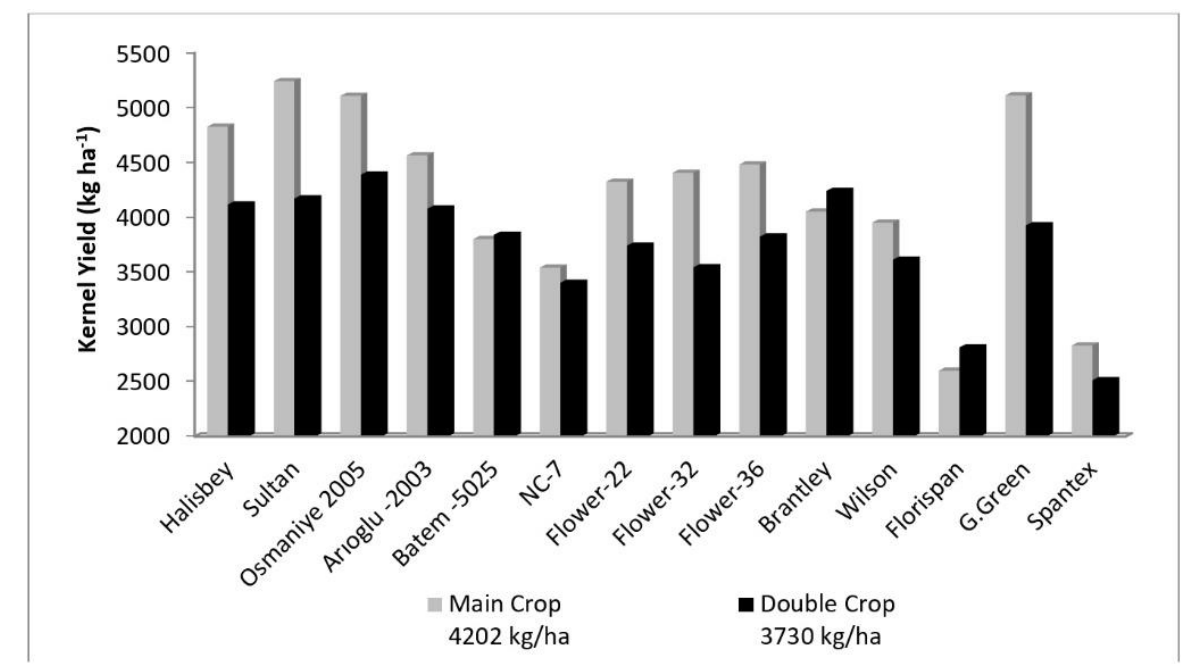

Figure 9. The Comparison of average kernel yield of peanut varieties grown in main and double crop growing seasons

The differences between the peanut varieties for the kernel yield were found statistically significant (Table 3). It can be seen in Figure 9, kernel yield ranged from 2830 to $5242 \mathrm{~kg} \mathrm{ha}^{-1}$ in different peanut varieties however, the highest kernel yield was obtained from Sultan $(5242 \mathrm{~kg}$ $\mathrm{ha}^{-1}$ ), G.Green (5112 $\mathrm{kg} \mathrm{ha}^{-1}$ ) and Osmaniye-2005 (5107 $\mathrm{kg} \mathrm{ha}{ }^{-1}$ ) varieties in main crop growing season. Kernel yield of peanut varieties were varied between 2513-4389 $\mathrm{kg} \mathrm{ha}^{-1}$ and among the peanut varieties the highest and the lowest kernel yield were obtained from Osmaniye-2005 (4389 $\mathrm{kg} \mathrm{ha}^{-1}$ ) and Spantex (2513 $\mathrm{kg} \mathrm{ha}^{-1}$ ) in double crop growing season. When the peanut varieties compared for the kernel yield at different growing seasons, the average yield values was $11.3 \%$ higher in main crop than in double crop growing season. Pod yield and shelling percentage are very important agronomic characteristics for the determination of kernel yield. The pod yield of peanut varieties was increased in main crop, whereas the shelling percentage was decreased. In this research, the pod yield was more effective than shelling percentage on calculation of kernel yield. Pod yield and the shelling percentage of the peanut varieties were found significant in different growing seasons due to their different genotypic background and genotype $\mathrm{x}$ environment interaction. For this reason, the kernel yield of peanut varieties has been observed to be different. The results indicated that according to two years average, between the growing season and variety interaction on kernel yield was statistically significant (Table 3). The highest kernel yield was obtained from Sultan $\left(5242 \mathrm{~kg} \mathrm{ha}^{-1}\right)$ in main crop and the lowest from Spantex $\left(2513 \mathrm{~kg} \mathrm{ha}^{-1}\right)$ in double crop growing season (Figure 9). Similar findings have been reported on peanut by Laurence (1983), Naab et al. 
(2004), Canavar and Kaynak (2008), Caliskan et al. (2008) and Abouziena et al. (2013).

\section{CONCLUSION}

The optimum air temperature ranges for vegetative growth in peanut is between 25 and $28^{\circ} \mathrm{C}$, which is slightly warmer than the optimum range reported for reproductive growth between 22 and $24^{\circ} \mathrm{C}$. High day temperature above $35^{\circ} \mathrm{C}$ during the reproductive phases reduce dry matter production, proportion of flowers forming pegs, number of pods per plant, individual seed mass, harvest index and pod yield. Crop management practices such as cultivar selection, time of sowing and growing period of varieties may influence the growth, yield and seed quality of peanut. Sowing time (growing season) is also one of the factors that play an important role on growth, yield and quality of peanut. Sowing date had a significant effect on pod yield, days to maturity, number of pods per plant, shelling percentage, pod yield per plant, 100-seed weight, oil and protein content.

Peanut are grown in different seasons such as main $(60 \%)$ and double crop $(40 \%)$ for the suitable climate in Mediterranean regions in Turkey. The yield and some agronomic and quality characteristics of peanut varieties are mainly affected by genotype and environmental conditions, particularly temperature during the growing season. This study was conducted to compare of agronomic and quality characteristics of some peanut (Arachis hypogaea L.) varieties grown as a main and double crop growing season. In this research, the average pod number, pod weight per plant, fancy pod percentage, protein and oil percentage, pod and kernel yield values of peanut varieties were higher in main crop than in double crop, whereas 100-seed weight and shelling percentage were higher in double crop than in main crop growing season. According to a two-year average, the pod yield per hectare of peanut varieties varied between $3366-8796 \mathrm{~kg}$ $\mathrm{ha}^{-1}$ and 3621-7094 $\mathrm{kg} \mathrm{ha}^{-1}$ main and double crop growing season, respectively. The average pod yield of peanut varieties were $6177 \mathrm{~kg} \mathrm{ha}^{-1}$ in main cropped, it was decreased to $5456 \mathrm{~kg} \mathrm{ha}^{-1}$ in double crop growing season. When the peanut varieties compared for the pod yield at different growing seasons, the average yield values was $11.7 \%$ higher in main crop than in double crop growing season. The highest pod yield was obtained from Sultan and Osmaniye-2005 varieties in both growing seasons.

\section{LITARATURE CITED}

Abouziena, H.F., M.S.A. Abd El Wahed, M.A.T. Eldabaa and E.R. El-Desoki. 2013. Effect of Ssowing date and reduced herbicides rate with additives an peanut (Arachis hypogaea L.) productivity and associated weeds. Journal of Applied Science research. 9(3):2176-2187

Anonymous, 2014a. FAO Production Year Book (www.fao.org).

Anonymous, 2014b. Turkish Production Year Book.

Anonymous, 2015. The meteorological data for Adana. The Turkish State Meteorological Service Adana Regional Directorship, 2013, 2014 and long term.

AOAC. 2010. Official methods of analysis of the association of analytical chemists. $18^{\text {th }}$ edition, Washington, D.C. USA
Arioglu, H.H. 2014. The oil seed crops growing and breeding. The publication of University of Cukurova, Faculty of Agriculture, No:A-70, 204 p. Adana-Turkey

Bala, H.B.M., V.B. Ogunlela, N.C. Kuchinda and B. Tanimu. 2011. Response of two groundnut (Arachis hypogaea L.) varieties to sowing date and NPK fertilizer rate in a semiarid environment: Yield and yield attributes. Asian Journal of Crop Science, 3(3):130-140

Brown, D.F., M.C. Carl, F.M. Karl and G.D. James. 1975. Effect of variety, growing location and their interaction on the fatty acid composition of peanut. J. Food Sci.40:1055-1060

Caliskan, S., M.E. Caliskan, M. Arslan and H. Arioglu. 2008. Effects of sowing date and growth duration on growth and yield of groundnut in a Mediterranean-type environment in Turkey. Field Crops Res., 105:131-140

Canavar, Ö. and M.A. Kaynak. 2008. Effect of different planting dates on yield and yield components of peanut (Arachis hypogaea L.). Turkish Journal of Agriculture and Forestry, 32:521-528

Canavar, Ö. and M.A. Kaynak 2010. Growing degree day and sunshine radiation effects on peanut pod yield and growth. African J. of Biotech, 9(15):293-301

Canvin, D.T. 1965. The effect of temperature on the oil content and fatty acid composition of the oils from several oilseed crops. Canadian J. of Botany, 43:63-69

Chowdhury, F.N., D. Hossain, M. Hosen and S. Rahman. 2015. Comperative study on chemical composition of five varieties of groundnut (Arachis hypogeal L.). World j. of Agricultural Science, 11(5)247-254

Cox, F.R. 1979. Effects of temperature on peanut vegetative and fruit growth. Peanut Science, 6:14-17

Gulluoglu, L., H. Bakal, B. Onat, C. Kurt, and H. Arioglu. 2016a. The effect of harvesting dates on yield and some agronomic and quality characteristics of peanut grown in Mediterranean region (Turkey). Turkish Journal of Field Crops. 21(2): 224-232

Gulluoglu, L., H. Bakal, B. Onat, A. El Sabagh, and H. Arioglu. 2016b. Characterization of peanut (Arachis hypogeal L.) seed oil and fatty acids composition under different growing season under Mediterranean environment. Journal of Experimental Biology and Agricultural Sciences, 4(5S):564571, DOI:http://dx.doi.org/10.18006/2016

Holaday, C.E. and J.L. Pearson. 1974. Effects of genotype and production area on the fatty acid composition, total oil and protein in peanuts. J. Food Sci,. 39:1206-1209

Isleib, T.G., B.L. Tilman, H.E. Patte, T.H. Sanders, K.W. Hendrix and L.O. Dean. 2008. Genotype-by-environment interaction for seed composition traits of breeding lines in the uniform peanut performance test. Peanut Science, 35:130-138

Ketring, D.L.1984. Temperature effects on vegetative and reproductive development of peanut. Crop Sci., 24:877-881

Knauft, A., A.J. Norden and D.W. Gorbet. 1986. The effect of three digging dates on oil quality, yield, and grade of five peanut genotypes grown without leaf spot control. Peanut Science, 13: 86-89

Kvien, C.S. and C.L. Bergmark.1987. Growth and development of the florunner peanut cultivars as influenced by population, planting date and water availability. Peanut science, 14:1116

Laurence, R.C.N. 1983. Effects of sowing date, spatial arrangement and population on yield and kernel weight of irrigated Virginia bunch peanuts. Austr. J. of Experimental Agric. and Animal husbandry, 23 (121):178-180

Naab, B.J., F.K. Tsigbey, P.V.V. Parasad, J.K. Boote, E.J. Bailey and L.R. Brandenburg. 2004. Effects of sowing date and fungicide application on yield of early and late maturing 
peanut cultivars grown under rainfed conditions in Ghana. Crop Prot., 24:325-332

Prasad, P.V., P.Q. Craufurd and R.J. Summerfield. 2000. Effect of high air and soil temperature on dry matter production, pod yield and yield component of peanut. Plant and Soil, 222:231-239

Raheja, R.K., S.K. Battai, K.L. Ahuja, K.S. Labana and M. Singh. 1987.Comparision of oil content and fatty acid composition of peanut genotypes differing in growth habit. Plant Foods for Human Nutrition, 37:103-108

Rasekh, H., J. Asghari, M.N. Safarzadeh Wishkai, S.L. Massoumi and R. Zakerinejad. 2010. Effect of planting pattern and plant density on physiological characteristics and yield of peanut (Arachis hypogaea L.) in Iran. Research J. of Biological Sciences, 5(8):542-547.

Sarkees, N.A. 2015. Effect of sowing dates on development, seed yield and quality of some peanut (Arachis hypogaea L.) genotypes. Jordan J. of Agricultural Sciences, 11(2):367-380

Savage, G.P. and J.I. Keenan. 1994. The composition and nutritive value of groundnut kernel. In Smart, J. (ed) The Groundnut Crop: A scientific basis for improvement. Chapman and Hall, London, pp 173-213

Woodroof, J.G. 1983. Peanuts: Production, processing, products. Third edition, Avi Publishing Company, Inc. Westport, Connecticut (USA), 414p. 